\title{
History in twentieth-century Ethiopia: The 'Great Tradition' and the counter-histories of national failure
}

\section{SARA MARZAGORA, SOAS UNIVERSITY OF LONDON}

\section{ABSTRACT}

Drawing from both fictional and non-fictional sources, this article traces the way history was conceptualised in twentieth century Ethiopia by secular educated elites, charting out the changing power relations between Ethiopia's hegemonic historiographical paradigm, and the alternative historical visions that challenged this 'Great Tradition' over the course of the century. While the Great Tradition extols Ethiopia's past and future glories, the counter-histories focused instead on the country's failure to develop and democratise. Against the interpretation that the counter-histories supplanted the Great Tradition in the late 1960s, the article examines them in terms of complementarity. The intellectual interventions of young student radicals in the late 1960 s constitute a break, but not a drastic paradigm shift, from the past. The Great Tradition had already been put into question by older generations of intellectuals, even if they proved unable or unwilling to translate their disillusionment in political action.

\section{INTRODUCTION ${ }^{1}$}

The interpretation of the Ethiopian past has been largely dominated, from the nineteenth century to the present, by a specific historiographical framework, variably called the 'Great tradition', 'Grand tradition', 'Ethiopianist tradition', 'Ethiopianist nationalism', 'Church and State tradition',

\footnotetext{
${ }^{1}$ There are no surnames in Ethiopian naming conventions and individuals are identified by their first name. As common in Ethiopian studies, in this article Ethiopian authors are cited by their first name followed by their father's name.
} 
This is the accepted version of a forthcoming article that will be published by Cambridge University Press in The Journal of African History: https://www.cambridge.org/core/journals/journal-of-african-history/all-issues

Accepted version downloaded from SOAS Research Online: http://eprints.soas.ac.uk/24350/

'Greater Ethiopia' approach or 'Pan-Ethiopian ideology'. This article maps out the origin and development of this hegemonic historiographical discourse. Mobilised by Ethiopian rulers to legitimise their power, the Great Tradition acted, throughout the history of the Ethiopian monarchy, as the dominant version of state nationalism. The historiographical influence of the Great Tradition has mostly derived from the position of socio-political power that its proponents have enjoyed within the Ethiopian state ${ }^{3}$. The rulers' political power and narrative power always went hand in hand, and statesponsored ideas of history were at their most influential when political power was successfully centralised and territorial control secured. The political centralisation characterising nineteenth century Ethiopia, for instance, was supported by, and in turn supported, a consolidation of the Great Tradition. Starting from the late 1960s, but more prominently in the past 30 years, scholars and political actors have complained that by retaining a monopoly over the way Ethiopia's past is interpreted, the Great Tradition has prevented a full-rounded understanding of Ethiopian history. This coincided, within Ethiopia and in the Ethiopian diaspora, with growing contestations of the state, in its borders and systems of institutionalised exclusions. New paradigms gained visibility first in the public arena, and subsequently in academic scholarship. As we shall see later in the article, a voluminous body of scholarly work has been produced to contest the Great Tradition's essentialist vision of identity, transcendental conception of history, unicentric and teleological orientation, and emphasis on concepts of continuity, indigeneity and unity.

In this article, I focus on the Amharic works produced by the Ethiopian intellectual elites close to the centre of the state in Addis Abäba, where most cultural infrastructures such as publishing houses, newspapers, schools, theatres, and bookstores were concentrated. Starting from a very restricted literate elite at the beginning of the century, the intellectual class gradually broadened with the opening of government-run schools in Addis Abäba and the launch of scholarship programmes for

\footnotetext{
2 C. Clapham, 'Rewriting Ethiopian history', Annales d'Éthiopie, 18 (2002), 38; D. Crummey, 'Ethiopian historiography in the latter half of the twentieth century: A North American perspective', Journal of Ethiopian Studies, 34:1 (2001), 8; Semir Yusuf, 'The politics of historying: a postmodern commentary on Bahru Zewde's History of Modern Ethiopia', African Journal of Political Science and International Relations, 3:9 (2009), 380, and A. Triulzi 'Battling with the past: new frameworks for Ethiopian historiography', in W. James at al. (eds.), Remapping Ethiopia: Socialism and After, (Athens, OH, 2002), 277, 279, and 282.

${ }^{3}$ Its scholarly weight has been further reinforced by the state-centric approach of much nineteenth and twentieth century historiography.
} 
This is the accepted version of a forthcoming article that will be published by Cambridge University Press in The Journal of African History: https://www.cambridge.org/core/journals/journal-of-african-history/all-issues

Accepted version downloaded from SOAS Research Online: http://eprints.soas.ac.uk/24350/

Ethiopian students to be trained abroad. The generation of the 'pioneers', born in the late nineteenth century and active before the Italian occupation, had high-profile ministerial and government jobs ${ }^{4}$. It was followed by two 'middle generations', one of thinkers born around the 1910s and one of thinkers born around the 1930s, who, while not necessarily high-level politicians, worked in public cultural institutions, and were very close to Emperor Haylä Səlasse. The Ethiopian Student Movement (ESM) of the 1960s and early 1970s represented a fourth generation of intellectuals, whose 'world of action', according to Andreas Eshete, starkly contrasted with the 'world of beauty' of their elders 5 .

This article's focus on secular intellectual elites - government workers, academics, fiction writers, civil servants, journalists, theatre directors, and university students - is far from painting a comprehensive picture of intellectual production in the period considered here. More scholarly attention should be devoted to the contributions of non-elite intellectuals. Alongside this elitist bias, Ethiopian intellectual history has also tended to overlook the work of religious scholars, and a comprehensive analysis of historical and political debates within religious institutions is still lacking. It is nevertheless important to counteract the simplistic notion of the secular supplanting the religious in intellectual history - the notion, that is, that intellectual history in Ethiopia was shaped in religious institutions before the twentieth century, and that from the twentieth century the only intellectual history that counts is the one produced in secular or state environments. On the contrary, religious scholars continued to contribute to political and historical debates, as shown by Messay Kebede in his study on aläka Asres Yenesew ${ }^{6}$. The contribution of religious scholars shows how history writing cannot be entirely subsumed under the banner of a "state ideological project", in Pietro Toggia's definition ${ }^{7}$. This holds true, to a certain degree, for the secular intellectual elites as well, whose relationship with state institutions, as we shall see, always retained an element of ambivalence.

\footnotetext{
${ }^{4}$ Bahru Zewde, Pioneers of Change in Ethiopia: The Reformist Intellectuals of the Early Twentieth Century, (Addis Ababa/Oxford, 2002).

${ }^{5}$ Andreas Eshete, 'Modernity: Its title to uniqueness and its advent in Ethiopia', Northeast African Studies, 13:1 (2013), 16.

${ }^{6}$ Messay Kebede, 'Return to the Source: Asres Yenesew and the West', Diogenes, 59:3-4 (2014), 60-71.

${ }^{7} \mathrm{P}$. Toggia, 'History writing as a state ideological project in Ethiopia', African Identities, 6:4 (2008), 320.
} 
This is the accepted version of a forthcoming article that will be published by Cambridge University Press in The Journal of African History: https://www.cambridge.org/core/journals/journal-of-african-history/all-issues

Accepted version downloaded from SOAS Research Online: http://eprints.soas.ac.uk/24350/

In the early 2000s calls to revise critical methods in Ethiopian historical studies multiplied, with weighty contributions by Bahru Zewde, Christopher Clapham, Alessandro Triulzi and Donald Crummey $^{8}$. Triulzi went back to his earlier reflections in a 2006 chapter, followed by further theoretical papers by Pietro Toggia, Semir Yusuf, Elena Vezzadini and Pierre Guidi ${ }^{9}$. In one way or another, all these scholars expressed dissatisfaction at contemporary historiographical practices in Ethiopian and Northeast African studies, and pushed for a comprehensive rethinking of analytical categories and frameworks ${ }^{10}$. Under particular attack came essentialised notions of ethno-religious identity, and the tendency to read history backwards at the service of present-day nationalist projects. In these scholarly surveys, the late 1960s are generally presented as a drastic turning point in Ethiopian historiography, when the Great Tradition was supplanted by alternative visions of history and nationhood.

While it cannot be denied that the generation of radical university students of the 1960s and early 1970s marked a break from previous intellectual production, I argue that there was more continuity between the students and their elders than previously acknowledged, and the students' historical vision did replicate some of the Great Tradition's methodologies. Rather than considering the 1960s as a 'paradigm shift' in Ethiopian historiography, a time when new historical conceptions supplanted old ones, I propose a two-tier model. Throughout the twentieth century, and up to the present, the Great Tradition, with its exceptionalism and exaltation of past and future glories, has always been accompanied by counter-historiographies based on anti-triumphalist ideas of failure. Before the 1960s, in works of the middle generations of Amharic-language intellectuals who were active in the post-liberation period, the counter-historiographies were constantly repressed, and only

\footnotetext{
${ }^{8}$ Bahru Zewde, 'A century of Ethiopian historiography', Journal of Ethiopian Studies, 33:2 (2000), 1-26; Clapham, 'Rewriting'; Triulzi, 'Battling'; D Crummey, 'The Horn of Africa: between history and politics', Northeast African Studies, 10:3 (2003), 117-38; and Crummey, 'Ethiopian historiography'.

${ }^{9}$ A. Triulzi, 'The past as contested terrain: commemorating new sites of memory in war-torn Ethiopia', in P. Kaarsholm (ed.), Violence, Political Culture and Development in Africa, (Oxford, 2006), 122-38; Toggia, 'History writing'; Semir, 'The politics'; and E. Vezzadini and P. Guidi, 'Contested memories, subalternity, and the state in colonial and postcolonial histories of Northeast Africa', Northeast African Studies, 13:2, (2013), 528.

${ }^{10}$ The debate has continued in many academic reviews of recent publications and in many non-academic blogs and online media.
} 
This is the accepted version of a forthcoming article that will be published by Cambridge University Press in The Journal of African History: https://www.cambridge.org/core/journals/journal-of-african-history/all-issues

Accepted version downloaded from SOAS Research Online: http://eprints.soas.ac.uk/24350/

occasionally emerged to the surface of historical discourse. Yet, the middle generations' disillusionment represented an essential backdrop against which the ideas of young student radicals were articulated. In turn, 'the intellectual culture and discourses that animated the Ethiopian student movement in the 1960s and 1970s have continued to impact political processes in the country in the generations since, ${ }^{11}$. The Great Tradition and the counter-historiographies proceeded parallel to one another during the course of the century, and both are alive and well even today.

\section{THE GREAT TRADITION}

The mythology that structured much of the historiographical claims of the Great Tradition takes the Kabrä Nägäst ('The Glory of Kings', fourteenth century) as its basis. Drawing on the legend of King Solomon and the Queen of Sheba present in a number of antecedent traditions, the Kabrä Nägäst narrates how the Ethiopians became God's new chosen people and how the Ark of the Covenant was transferred from Jerusalem to Aksum. The protagonist of the new covenant with God was the son of Solomon and Sheba who went on to rule 'Ethiopia' after his mother's death, founding a new 'Solomonic' ruling dynasty. The Kabrä Nägäst defined an ideology of chosenness that, in Geez medieval and early modern works, was often translated into a hierarchical civilizational distinction between Christian centres and non-Christian peripheries ${ }^{12}$. This unicentric tendency to assimilate 'all historical discourse into the worldview of the author or his protagonist, reserving little room for alternative voices' made the Great Tradition 'highly monoglossic'13. For Belcher, 'the Habesha's success in projecting themselves as exceptional has come at the tremendous cost of others ${ }^{14}$, leading to systematically pejorative depictions of groups such as the Oromo, the Agaw, Muslims and the Ethiopian Jews. Ethiopian Muslims, for example, were described in Ethiopian chronicles 'through the

\footnotetext{
${ }^{11}$ Elleni Centime Zeleke, 'When social science concepts become neutral arbiters of social conflict: Reading the Ethiopian federal elections of 2005 through the Ethiopian Student Movement of the 1960s and 1970s', Northeast African Studies, 16:1 (2016), 107.

${ }^{12}$ Hussein Ahmed, 'The Historiography of Islam in Ethiopia', Journal of Islamic Studies, 3:1 (1992), 15-46.

${ }^{13}$ J. De Lorenzi, Guardians of the tradition: Historians and Historical Writing in Ethiopia and Eritrea, (New York, 2015), 31.

${ }^{14}$ W. Belcher, Abyssinia's Samuel Johnson: Ethiopian Thought in the Marking of an English Author (Oxford, 2012), 31 .
} 
This is the accepted version of a forthcoming article that will be published by Cambridge University Press in The Journal of African History: https://www.cambridge.org/core/journals/journal-of-african-history/all-issues

Accepted version downloaded from SOAS Research Online: http://eprints.soas.ac.uk/24350/

eyes of some other group - generally from the point of view of those who had political and ideological reasons to see them as foreign to Ethiopia itself. ${ }^{15}$

Ethiopia's thousand-year monarchical saga is told as part of a transcendental time: that of God and Christianity. Historical actors are judged based on their moral standing in the polarity between good and evil, God and Satan, Christians and infidels. These roles and their significance

derived from the all-encompassing religious-historical process that began with the events of the scriptures, continued through the early Church, culminate in the flourishing of the true faith in Ethiopia, and would continue to unfold as foretold in prophecy and described in eschatological literature. Individual agents -whether good or evil- were through their moral roles major and minor players in this universal history, much as they were in the Hebrew and Christian scriptures ${ }^{16}$.

Accompanying the teleological unfolding of such monarchy-centred and divinely-ordained history is a static and stable identity, whose contours are described in a normative and essentialist way. The institution of the monarchy is presented as both the moulder and the guarantor of this identity - a notion that remained at the core of the Great Tradition all the way up to the twentieth century.

\section{THE BEGINNING OF THE TWENTIETH CENTURY}

The beginning of the twentieth century was marked by profound changes in the configuration of Ethiopia as a polity. In the new international system resulting, Solomonic emperors came to rule a precisely-defined and contractually-demarcated territory, in accordance with newly-minted international legal concepts. The idea of Ethiopia became anchored for the first time to a fixed geographic space and acquired a clearly defined cartographical identity, with internationallyrecognised boundaries. The borders newly delineated in the 1890s and 1900s were located, as a result of Mənilək II's military campaigns of the 1880s and 1890s, much farther afield than the traditional

\footnotetext{
${ }^{15}$ Hussein, 'The historiography', 19.

${ }^{16}$ De Lorenzi, Guardians, 25.
} 
This is the accepted version of a forthcoming article that will be published by Cambridge University Press in The Journal of African History: https://www.cambridge.org/core/journals/journal-of-african-history/all-issues

Accepted version downloaded from SOAS Research Online: http://eprints.soas.ac.uk/24350/

territorial core of the Solomonic polity. The transformation of the Solomonic empire into a sovereign state in the modern sense required a correspondent reconfiguration of state nationalism. The Abyssinian Empire had already been multicultural, multireligious and multilingual, but the range and scale of ethnic diversity encompassed by Mənilək II's new state was unprecedented, and required Ethiopian leaders to rethink ideas of nationhood and develop additional policies for the new provinces.

The necessity to ideologically situate Ethiopia in the rapidly-globalising international environment, an environment to which Ethiopian intellectuals were exposed in significantly higher numbers and to a drastically more extensive degree than in the past, gave a renewed prominence to debates about national identity. How to make sense of Ethiopia's new place in the international system of states and market economies? It was around the core components of the Great Tradition that a first set of debates concentrated: the function of the monarchy in the context of new normative ideas of statehood; the notion of national unity in the context of Ethiopia's multi-ethnic state; the role of religion as an instrument of political (and particularly monarchical) legitimation; the significance of Christianity as a founding principle of public morality and the law.

Another area of intellectual ferment revolved around models of world history. How should Ethiopian intellectuals appraise the imperial ideologies attached to the international system? Narratives of modernity and progress offered unifying and far-reaching explanations to global historical development. In historiography, this led to a revival of the teleological conception of history inspired by the Christian doctrine. At the level of state narrative, the Christian teleology was secularised into an equally teleological theory of modernisation that emphasised state-building, industrialisation and science. Progress - mostly conceived as military reforms, technological advancement, infrastructural development and institutional centralisation - became the self-proffered mission of the state.

These debates, with the new inputs coming from abroad, made the first decades of the twentieth century particularly creative from the point of view of history writing and political thought. 
This is the accepted version of a forthcoming article that will be published by Cambridge University Press in The Journal of African History: https://www.cambridge.org/core/journals/journal-of-african-history/all-issues

Accepted version downloaded from SOAS Research Online: http://eprints.soas.ac.uk/24350/

Ethiopian scholars such as Gäbrä-Həywät Baykädaň (1886-1919), Afäwärḳ Gäbrä-Iyyäsus (18681947), Həruy Wäldä-Səlasse (1878-1938) and Tayyä Gäbrä-Maryam (1860-1924) started experimenting with new historical themes, methods and analytical tools ${ }^{17}$. For all of them, ideas coming from Western Europe were a central source of inspiration. And yet, in terms of theoretical weight and practical effects, the way these intellectuals appraised, adopted, promoted or rejected Western ideas was marginal compared to their identification with the Great Tradition. The most urgent problem for the new generations of historians was precisely how to renew and reenergise the inherited historiographical tradition in the changed socio-political environment of the new century. The methodological and theoretical innovations in history writing from the period are therefore the product of widespread nationalist concerns. Although individual solutions differed from one historian to the other, all held a Christian and habäša-centric outlook in common and all endorsed the country's monarchical ideology.

De Lorenzi uses the term 'domestication' to describe how 'vernacular historical writing was not westernized; instead, Western historiography was indigenized. ${ }^{18}$ He illustrates this point via the work of Gäbrä Krestos Täklä Haymanot. In his 1924 Aç̣̣̌ər YäAläm Tarik Bamarəňňa ('Short history of the world in Amharic'), Gäbrä Krestos expands the Solomonic focus of traditional vernacular historiography to look at global processes of societal change. On the surface, Short History embraces a teleology of progress outwardly reminiscent of the European Enlightenment. Gäbrä Krestos understands human difference via the Western distinction of civilised and uncivilised people, for example. Upon closer inspection, though, his work significantly diverges from Western frameworks, and shows in fact a pronounced hostility towards the universalist claims of Western historical paradigms. The notion of progress does not allude to the gradual spreading of freedoms, rights, and democracy, but rather to the divinely-ordained spread of Christianity as faith and as the organising principle of politics. It is Christianity that defines the different stages of human development, and

\footnotetext{
${ }^{17}$ Gäbrä-Həywät Baykädaň, Ațe Məniləkənna Ityopya [Mənilək and Ethiopia, 1912]; Afäwärk Gäbrä-Iyyäsus, Dagmawi Mənilək Nəgusä Nägäst ZäItyopya ['Emperor Mənilək of Ethiopia', 1909]; Həruy Wäldä-Səlasse, Yährywät Tarik ['Biographies', 1922/23] and YäItyopya Tarik ['History of Ethiopia', 1935/36]; and Tayyä Gäbrä-Maryam, YäItyopya Hozb Tarik ['History of the people of Ethiopia', posthumous 1971/72].

${ }^{18}$ De Lorenzi, Guardians, 10.
} 
This is the accepted version of a forthcoming article that will be published by Cambridge University Press in The Journal of African History: https://www.cambridge.org/core/journals/journal-of-african-history/all-issues

Accepted version downloaded from SOAS Research Online: http://eprints.soas.ac.uk/24350/

Ethiopia, whose monarch was tasked with preserving the country's age-old faith, was therefore to be counted among the world's developed and advanced nations. Gäbrä Krestos’s teleology, De Lorenzi concludes, is far from Eurocentric in this.

In the attempt to hybridise local and foreign historiographical paradigms, two foundational aspects were reinstated that came to define the Great Tradition in the twentieth century. The first were moral codes, and the second were socio-political hierarchies. The two are closely interlinked, as the monarch was considered the main agent of progress, and progress was conceived on the basis of Christian eschatology. Class hierarchies were thought to be divinely ordained. The Emperor, leading society from the top, had a simultaneous secular and religious mandate. Western societies were found lacking for not having an ethical guarantor to lead them, and Ethiopian thinkers 'questioned the adequacy of the West's ideology for the life of the nation without the moral quest and activism of a divine monarch. ${ }^{19}$ Historical progress was thus conceived as a 'part of a transcendent kingly moral insight' ${ }^{20}$

The intellectual creativity of the beginning of the twentieth century corresponded with a rather fluid political situation, with different contenders for power and some weighty alternative conceptions of the state, most notably the multireligious and multicultural vision of Lajj Iyasu. By contrast, the centralisation of the political arena from the 1930s - when Ras Täfäri consolidated his power and the intellectual class became heavily dependent on his personal patronage - led to a progressive rigidification of both political thought and historiographical practice.

\section{POST-1941}

It is after 1941, at the height of Haylä Səlasse's power, that the Great Tradition acquired a fixed, distinctive and formulaic identity. When scholars today talk about the hegemony of the Great Tradition in Ethiopian studies, they are really referring to a distinctive, but fairly loose tradition that

\footnotetext{
${ }^{19}$ Elizabeth Wolde Giorgis, 'Charting out Ethiopian modernity and modernism', Callalao, 33:1 (2010), 90-91.

${ }^{20}$ Elizabeth, 'Charting', 91.
} 
This is the accepted version of a forthcoming article that will be published by Cambridge University Press in The Journal of African History: https://www.cambridge.org/core/journals/journal-of-african-history/all-issues

Accepted version downloaded from SOAS Research Online: http://eprints.soas.ac.uk/24350/

was fixed into a stable 'discourse' in the post-1941 period. History-writing in the Christian highlands had always been concerned with big men (and occasionally women), whether rulers or religious figures. This top-down approach became in the 1950s and 1960s even more state-centric, in parallel with the nation-building perspective of post-independence African historical studies. Exceptionalist claims continued to underpin the narration of history in line with the Great Tradition, particularly as a means to distinguish Ethiopia from the rest of sub-Saharan Africa and claim a civilizational prestige at least equal to those of Western nations. The temporal continuity of a supra-historical 'Ethiopian' nation, encased in successive and contiguous imperial polities, acquired a renewed importance. Opening the Great Tradition's plot was usually the Aksumite Empire, one of the great world powers alongside Rome, Persia and China and one of the first nations to convert to Christianity. Heir to the Aksumites, the Zagwe dynasty built the famous rock-hewn churches at Lalibäla. Yəkunno Amlak's Solomonic 'restoration' in 1270 established a dynasty that lasted up to $1974^{21}$. In its teleological framework, historical moments of weakened imperial control or centrifugal political tendencies are presented as momentary interruptions of the nation's forward march.

Haylä Səlasse proactively intervened in regulating the way Ethiopian history was written both domestically and abroad. His autobiography in two volumes (and its prompt translation into English) was central to the Emperor's 'historiographical manipulation ${ }^{22}$. He concealed or destroyed works that presented alternative visions of history. The period before his coronation in 1930 in particular was subject to close imperial scrutiny, for the need to keep as much as possible out of sight the legally murky circumstances in which Täfäri had risen to power in 1916 and the violent power struggles characterising his regency. Similarly, he personalised and monopolised relations with Westerners present in Ethiopia, making sure that the visitors' interpretations of Ethiopian history were always mediated, and as far as possible controlled, by the imperial court.

\footnotetext{
${ }^{21}$ One of the main characteristics of the Great Tradition is the ahistorical use of the word 'Ethiopia' to describe both the Abyssinian Empire and the modern Ethiopian nation-state.

${ }^{22}$ H. Rubinkowska, 'The history that never was: Historiography by Haylä Ś̉llase I', in V Böll et al. (eds.), Studia Aethiopica: In Honour of Siegbert Uhlig on the Occasion of his 65th Birthday (Wiesbaden, 2004), 221232.
} 
This is the accepted version of a forthcoming article that will be published by Cambridge University Press in The Journal of African History: https://www.cambridge.org/core/journals/journal-of-african-history/all-issues

Accepted version downloaded from SOAS Research Online: http://eprints.soas.ac.uk/24350/

The development of Ethiopia's cultural and educational infrastructures in Addis Abäba was instrumental to this process of ideological consolidation. The Great Tradition was gradually institutionalised with the preparation of history textbooks for the growing number of primary and secondary state schools in the post-1941 period, and was codified as academic genre with the founding of the Institute of Ethiopian Studies (1962) and the Department of History (1963-4) at Haylä Səlasse I University. This new academic kind of historiography, according to James de Lorenzi, tended to reference Western models much more directly, leading to the emergence of and a new kind of developmental historicism based on modernisation theory ${ }^{23}$. Alongside these 'scientific' conceptions of historical studies, old models continued to thrive - for example in the figure of TäkläȘadək Mäkwəriya (1913-2000), whose works of vernacular historiography proved very popular and circulated broadly.

The vast majority of cultural facilities were state-owned and state-controlled, with a system of censorship in place since the 1920 s that became more systematic in the post-1941 period. Only by demonstrating at least a certain degree of loyalty towards the government could an intellectual rise to prominence and have their work published. A process of self-selection was therefore in place whereby only certain versions of history had the institutional backing to be circulated, in turn reinforcing the hegemony of the Great Tradition as state nationalism. Those thinkers that attempted to revise the unicentrality of the Great Tradition were quickly marginalised. Yəlma Däressa, for example, was allegedly removed from his post of Minister of Finance because of the discontent generated by his 1967 study of $16^{\text {th }}$ century Ethiopia, in which he was accused of giving too much space to the Oromo invasion and overestimating its impact ${ }^{24}$.

\footnotetext{
${ }^{23}$ De Lorenzi, Guardians, 114ff.

${ }^{24}$ Paulos Milkias 'Yolma Däressa', in A. Bausi (ed.), Encyclopaedia Aethiopica, Y-Z. (Wiesbaden, 2014$), 47$.
} 
This is the accepted version of a forthcoming article that will be published by Cambridge University Press in The Journal of African History: https://www.cambridge.org/core/journals/journal-of-african-history/all-issues

Accepted version downloaded from SOAS Research Online: http://eprints.soas.ac.uk/24350/

THE $1960 \mathrm{~S}$

In late 1960s and early 1970s Ethiopian historiography went through a profound 'representational crisis ${ }^{25}$. While the old intellectuals shared high levels of ideological similarity, the student generation was responsible for a considerable change in the history of Ethiopia's political thought. This break was emphasised by the students themselves, whose publications increasingly antagonised their seniors and claimed for themselves a new, and radically different, socio-political and ideological identity. The old intellectuals voiced in their works a corresponding detachment from their younger counterparts. Although the different generations frequented the same social and cultural spaces in the city, intellectual exchanges between them were limited, and collaboration even rarer.

University students opposed the monarchy and called for a profound restructuring of both class relations and interethnic hierarchies ${ }^{26}$. The Great Tradition was denounced as the legitimation tool of repressive policies of centralisation and cultural assimilationism. Students wrote against some of the key components of the Great Tradition: its habäs̆a-centrism and exceptionalism, for example, together with its transhistorical view of the nation as always-already existing. The monarchy was for them just a 'fettering dictatorship'27. Demonstrations were organised to demand freedom of expression and an expansion of civil liberties. Students denounced the exploitation of the peasantry and called for comprehensive agrarian reform - a topic older generations of intellectuals had already been advocating since the beginning of the century. The students reframed the issue by mobilising the analytic category of 'feudalism', which was increasingly adopted to describe Ethiopia's exploitative class system. The ESM's political agenda shifted from reformist calls to democratisation at the beginning of the 1960s to revolutionary calls to overthrow Haylä Səlasse via armed struggle. The experiences of Ethiopians studying in the West at the time of black rights movements and the radicalising presence of African students on scholarship programmes in Addis Abäba pushed the ESM

\footnotetext{
${ }^{25}$ Toggia, 'History writing', 320.

${ }^{26}$ R.R. Balsvik, Haile Sellassie's Students: The Intellectual and Social Background to Revolution, 1952-1977 (East Lansing, 1985)

${ }^{27}$ quoted in Bahru Zewde, The Quest for Socialist Utopia: The Ethiopian Student Movement, C.1960-1974, (Woodbrigde/Rochester, 2014), 125.
} 
This is the accepted version of a forthcoming article that will be published by Cambridge University Press in The Journal of African History: https://www.cambridge.org/core/journals/journal-of-african-history/all-issues

Accepted version downloaded from SOAS Research Online: http://eprints.soas.ac.uk/24350/

to advocate for black rights and oppose European colonialism and neo-colonialism in Africa. As for the contestation of interethnic hierarchies privileging the habäs̆a over other Ethiopians, the so-called ‘national question’ was first articulated in 1969, when an undergraduate student, Walälləň Mäkonnən, published a now-famous article in which he criticised the imperial idea of nationhood as based on 'Amhara-Tigre supremacy' over the other Ethiopian 'nations ${ }^{28}$.

While, in the perception of actors at the time, the gulf between old and new positions seemed unbridgeable, the students' ideas had in fact elements of continuity with the political thought of previous generations. In historiography, the theological outlook of earlier descriptions of the past was condemned, and historical materialism became the preferred methodology. And yet, as Messay Kebede has argued, religious morality and religious dogmatism were important factors in the radicalisation of the student movement. Student leaders 'put the noble sentiments of Christianity at the service of the new ideology of Marxism-Leninism. ${ }^{29}$ Not only did Marxism reconfirm the previous teleological reading of history, but it also sustained an epistemology that, like previous ones, tended towards universalistic assumptions ${ }^{30}$. The tendency to cast actors in moral roles did not disappear, but 'good' and 'evil' were now equated to being for or against the masses. The description of a revolutionary rural insurgency spoke to Marxist thinkers as much as referring back to the imaginary of shaftannät $t^{31}$. More importantly, the students saw themselves as the generation that would fulfil the country's destiny of greatness, and Marxism was chosen as the most suited framework to implement the programme of modernisation with which all previous generations of intellectuals had been extensively concerned. The fact that the 'national question' appeared so late in the movement, and remained extremely divisive, shows the resilience of past ideas of 'Greater Ethiopia' and national unity.

\footnotetext{
${ }^{28}$ Walleligne Mekonen [Walällən̆ Mäkonnən], 'On the question of nationalities in Ethiopia', Struggle, 5:2, (1969), 4-7.

${ }^{29}$ Messay Kebede, Radicalism and Cultural Dislocation in Ethiopia, 1960-1974, (Rochester, 2008), 133.

${ }^{30}$ Elleni Centime, 'When social science', 125.

${ }^{31}$ Militias in rural or mountainous terrains engaged in banditry or rebellions against the central authority.
} 
This is the accepted version of a forthcoming article that will be published by Cambridge University Press in The Journal of African History: https://www.cambridge.org/core/journals/journal-of-african-history/all-issues

Accepted version downloaded from SOAS Research Online: http://eprints.soas.ac.uk/24350/

Much of today's historiography on the ESM has been written by former members of the movement, who, over the years, have retained some of the same perspectives they held during their youth. Most notably, former ESM historians have continued portraying the old generations in the same way, reiterating previous accusations of co-option and political subservience. Bahru, for example, brushes aside the contribution of the middle generations by claiming that 'quite in contrast to the intellectual vibrancy that prevailed in the 1920 s, the post-Liberation years were characterized by an assiduous cultivation of the emperor's personality cult. ${ }^{32}$ The educated elite of the post-1941 period, in his analysis, 'saw its mission as one of loyal and dedicated service rather than engagement in social and political critique. ${ }^{, 33}$

These accusations are well founded. In the works they published in the 1960s, the older generations of intellectuals made similar accusations against their generational peers. And yet, although the old elites remained a pro-establishment force, they did question the Great Tradition. Some of them were sympathetic towards or proactively supported the student movement. During his BA at Haile Selassie I University (1960-64), Daňňaččäw Wärḳu was partly involved in student politics and wrote protest poems. He went on to become a lecturer at the university (1964-69), and agreed with the need for deep reforms, but never embraced Marxism. As a lecturer, he kept his distance from the student movements, whose motives he approved and whose proactive commitment he admired, without agreeing with their proposed solution. Intergenerational political collaboration remained informed by the teacher/student power dynamic, but within this context some teachers, like Yohannes Admasu, openly embraced the students' struggle, writing fictional and non-fictional pieces in support of students' radical activism.

No comprehensive study has been carried out on the two generations of thinkers in between the first pioneers at the beginning of the century and the students in the 1960s. The middle generations ostensibly supported the Great Tradition, but it is possible to trace in their works, though scattered among the usual nationalist slogans, hints of more disillusioned vision of histories. Was the nation

\footnotetext{
${ }^{32}$ Bahru Zewde, The Quest, 36.

${ }^{33}$ Bahru Zewde, Pioneers, 211.
} 
This is the accepted version of a forthcoming article that will be published by Cambridge University Press in The Journal of African History: https://www.cambridge.org/core/journals/journal-of-african-history/all-issues

Accepted version downloaded from SOAS Research Online: http://eprints.soas.ac.uk/24350/

building failing? Had it failed already? Was it still possible for Ethiopia to achieve the modernisation that the Emperor had promised?

Within the Great Tradition, the victory at Adwa was thought to usher a future of progressive grandeur, comparable to those of 'modern' European nations. However, as time went on, the more a distance grew between the expected glory of the country and the reality of its perceived underdevelopment. Ethiopia's 'separate destiny' started to be seen as a burden rather than a privilege. Adwa was thus cast as a broken promise, and the patriotism it kept inspiring became infused with a sense of unfulfillment. The belief, boosted by Adwa, in Ethiopian exceptionalism made it all the more disappointing for the intellectuals to look at Ethiopia's lack of progress. The promise of Adwa was from its beginning intertwined with a feeling of inexplicable and unmerited decadence. The perceived decline was believed to be reversible, a temporary misfortune that did not invalidate Ethiopia's claim to be among the world's greatest nations. This assumption, though, did not solve the dissonance between the destiny of greatness foretold by the Great Tradition and the reality of the country's perceived underdevelopment. A more pessimistic vision of history soon took shape, sceptical of the Great Tradition's tales of Ethiopia's imminent success. In their critique of Ethiopia's backwardness, the generation of the pioneers, according to Bahru, 'represented a counter-current to the smug confidence that had ensued after Adwa. They advocated a series of reforms in order to give socioeconomic content to the political independence that Adwa had guaranteed. ${ }^{34}$ Such counterhistoriography suggested that Adwa marked Ethiopia's 'separate decline', rather than its separate glory. It deconstructed Adwa's mythical status in Ethiopian history arguing that Adwa-inspired nationalism precluded a realistic assessment of the country's condition and discouraged a committed effort to strengthen Ethiopia's military, political and diplomatic position.

This counter-historiography of national failure, although born in the immediate aftermath of the Adwa victory, was never comprehensively articulated in the works of the first three generations of twentieth-century intellectuals. Censorship prevented discussing Ethiopia's progress in disenchanted

\footnotetext{
${ }^{34}$ Bahru Zewde, A History of Modern Ethiopia, 1855-1974, (London, 1991), 110.
} 
This is the accepted version of a forthcoming article that will be published by Cambridge University Press in The Journal of African History: https://www.cambridge.org/core/journals/journal-of-african-history/all-issues

Accepted version downloaded from SOAS Research Online: http://eprints.soas.ac.uk/24350/

terms, but more important than the hindrance of censorship was the intellectuals' reluctance to abandon the reassuring optimism of the Great Tradition. Feelings of disillusionment were immediately suppressed and, in the production of Ethiopian intellectuals, only surfaced sporadically, in momentary outbursts of frustration.

The newspaper Barhanənna Sälam offers some examples. On 23 December 1926, Blatta Däressa Amänte laments Ethiopia's lack of progress. Adwa, he says, should have inspired the Ethiopians to build more factories, like Japan did, but instead of living up to the promises of Adwa, Ethiopia was wasting the opportunity, with year after year of stagnation ${ }^{35}$. In his 1922 YäItyopya Həzb Tarik ('History of the people of Ethiopia'), Tayyä Gäbrä-Maryam bemoans Ethiopia's fall from grace: 'such a beautiful country and an object of admiration for foreigners has now become the citadel of bloodshed, injustice, evil and shame because her unity has been destroyed through discord. ${ }^{36}$ In his Ațe Məniləkənna Ityopya ('Emperor Mənilək and Ethiopia'), Gäbrä-Həywät Baykädaň unfavourably compares Ethiopia with British Sudan and Italian Eritrea ${ }^{37}$; but some of his contemporaries went even further, and momentarily flirted with the idea that Ethiopia would benefit from being colonised. In 1925, Wärḳənäh Әšäte confessed his frustration to British Foreign Office agents at the Orthodox Church's opposition to the reforms he and Täfäri were attempting to implement, and proposed to resolve the standoff by devolving part of Ethiopia's sovereignty to the League of Nations. A temporary mandate over the country exercised by two or three powers, Wärḳınäh reasoned, could provide the initial push Ethiopia needed to start her process of modernisation ${ }^{38}$. In his unpublished autobiography (written after the Italian occupation), Täklä-Hawaryat Täklä-Maryam ventures even further:

Sometimes, I ask myself, would it have been better if the civilized nations had colonized us for a short period of time? The British had that opportunity twice [1868 and 1941]. But,

\footnotetext{
${ }^{35}$ Barhanənna Sälam, 23 December 1936.

36 Tayyä Gäbrä-Maryam, History of the People of Ethiopia, trans. G Hudson and Tekeste Negash (Uppsala, 1987 [1922]), 96.

${ }^{37}$ Gäbrä-Həywät, Ațe Mənilakənna, 139.

${ }^{38}$ Bahru, Pioneers, 104-5.
} 
This is the accepted version of a forthcoming article that will be published by Cambridge University Press in The Journal of African History: https://www.cambridge.org/core/journals/journal-of-african-history/all-issues

Accepted version downloaded from SOAS Research Online: http://eprints.soas.ac.uk/24350/

because they were not prepared to help, they left the country without setting up anything ${ }^{39}$.

This was, for Täklä-Hawaryat, just a transitory thought, which he allowed himself to express only in the confessional, private context of his autobiographical writing. Considering his implacable opposition to the Italian occupation, this passage 'is a measure of [Täklä-Hawaryat's] disenchantment with the country's state of affairs. ${ }^{40}$

The fact that Täklä-Hawaryat expressed this view after the Italian occupation is significant. The fascist conquest inflicted a significant blow to the self-assurance of the post-Adwa years. The impacts of the occupation were rarely discussed in the open, and the government tried to minimise the 'Italian incident' as much as possible. But some intellectuals did reflect, albeit in passim, on how the Italian years had made apparent Ethiopia's political, military and economic weakness. 'The reigns of Emperors Tewodros, Yohannes and Menelik have passed in vain', declared a disheartened Käbbädä Mikael in his Japan Әndämən Sälätțänäčč ('How Japan modernised'). 'If Ethiopia had worked hard [in adopting European ways] in those years', he reasons, 'she would have averted the recent Fascist invasion. ${ }^{41}$

With the tightening of censorship in the post-1941 period, creative literature became one of the main venues in which these disillusioned histories had a chance of being articulated. Both Gərmaččäw Täklä-Hawaryat's 1948/49 Araya and Asäffa Gäbrä-Maryam’s 1953/54 Ondäwatțačč Karračč ('She went out and never came back') strongly criticise of the excess of confidence of the Ethiopian political elites before the Italian invasion. They present this complacency and hollow pride as one of the main causes of the Ethiopian capitulation at Mayc̣̆äw. In Araya, Ato Alämayähu, a veteran of Adwa, reacts with smugness at the news, in 1935, that the Italians were about to invade Ethiopia a second time. He reminds Araya that at Adwa the Italians were defeated only with sticks and spears, but Araya is not so optimistic. He points instead at the differences in preparation and

\footnotetext{
${ }^{39}$ Quoted in Bahru, Pioneers, 100.

${ }^{40}$ Bahru, Pioneers, 100.

${ }^{41}$ Quoted in Bahru Zewde, Society, State and History, (Addis Ababa, 2008), 199.
} 
This is the accepted version of a forthcoming article that will be published by Cambridge University Press in The Journal of African History: https://www.cambridge.org/core/journals/journal-of-african-history/all-issues

Accepted version downloaded from SOAS Research Online: http://eprints.soas.ac.uk/24350/

organisation between the two armies, worrying in particular about the Italian war planes, whose presence, he forecasts, could be decisive. Ato Alämayähu and his boastings about Ethiopia's military invincibility, of course, are later proven wrong. Asäffa Gäbrä-Maryam is even harsher with the old generations. Zälläḳa, the novel's protagonist, blames his father and father-in-law, two Adwa veterans, for their arrogance. His generational peers have inherited, without questioning it, the same selfassuredness, and are for Zälläḳa as responsible for Ethiopia's defeat as their fathers for neither realised that Ethiopia in 1935 was unprepared, underequipped and badly organised. The government indulged in the feeling of Adwa's nationalist grandeur, failing to realistically assess the threat, and Zälläḳa condemns it in unambiguous terms: 'a people or government that fails to closely follow and trace the hourly, daily, monthly and yearly plan of his neighbour, let alone that of his enemy, cannot claim to be a nation or a government. ${ }^{, 42}$

These contrasting feelings of pride and frustration characterised visions of national history ever since, infusing them with a basic ambivalence. Ethiopian intellectuals came to be driven 'by the cognitive dissonance between an inherited sense of cultural superiority and acute awareness of Ethiopian "backwardness", by contrast not only with the European states [...] but even with colonized African people whom they were accustomed to treat with scorn. ${ }^{43}$ For the old generations, "the imagination of the nation that was replete with exceptionalism reduced sentiments of alterity just as it exacerbated its sensitivity. ${ }^{44}$ The Ethiopian elites around the Emperor approached the idea of nation with simultaneous patriotism and disappointment.

In the first half of the twentieth century up to the 1960 s, the two historical perspectives existed alongside one another. The Great Tradition was dominant, in full view, officially endorsed by Ras Täfäri/Haylä Səlasse and championed by the vast majority of intellectuals close to him. Alongside the Great Tradition, the feeling of frustration, of 'separate decline', imbued Ethiopian historiography in a less open, but yet perceivable way. Rather than following the teleological unfolding of Ethiopia's

\footnotetext{
${ }^{42}$ Asäffa Gäbrä-Maryam, Әndäwatțačč Karračč, (Addis Ababa, 1953/54), 34.

${ }^{43}$ C. Clapham, 'Ethiopian development: the politics of emulation', Commonwealth \& Comparative Politics, 44:1 (2006), 141.

${ }^{44}$ Elizabeth, 'Charting', 92.
} 
This is the accepted version of a forthcoming article that will be published by Cambridge University Press in The Journal of African History: https://www.cambridge.org/core/journals/journal-of-african-history/all-issues

Accepted version downloaded from SOAS Research Online: http://eprints.soas.ac.uk/24350/

unique destiny of glory, the historiographies of disillusionment emphasised ruptures, gaps, and failures. While the Great Tradition chronicled the past glories of the Ethiopian state, these underground counter-histories looked at those past glories as many broken promises in the history of the country. The focus was on the things Ethiopia could have become, and did not, unable to live up to its celebrated history. The occasional outpourings of disappointment and frustration that dotted the works of many intellectuals never concretised into a systematic reappraisal of the Great Tradition. Feelings of failure and decline were constantly repressed, whether consciously or unconsciously.

Why the repression? On a superficial level, the lack of freedom of expression under Haylä Səlasse made it dangerous to disagree with the state's nationalist rhetoric. This is why alternative visions of history only make sporadic appearances in written works of the period. Yet, the old intellectuals did not take advantage of the few existing avenues to circumvent censorship and express dissent, thus validating Bahru's accusation of social co-option. On a deeper level, though, the inability to transcend the Great Tradition was experienced by the middle generations as a shattering ideological paralysis, and the sense of powerlessness and purposelessness generated a widespread anxiety. Many of them started decrying the failure of the intellectual class, of the Great Tradition - perhaps of history in general, as suggested by Șägaye Gäbrä-Mädhən in his 1965 poem 'Also of Etiopics':

We are to know

$[\ldots]$

Of the days when we tottered and paddled on our fours

While our little legs were yet playing us false

Of the songs of the past our elders taught us

The songs when time was of little or of no concern

When these giant mountains swallowed in

The deaf pride of antiquity

And frowned away at the winds of change:

$[\ldots]$ 
This is the accepted version of a forthcoming article that will be published by Cambridge University Press in The Journal of African History: https://www.cambridge.org/core/journals/journal-of-african-history/all-issues

Accepted version downloaded from SOAS Research Online: http://eprints.soas.ac.uk/24350/

We, whose wake is rooted

In the moaning groins of yesteryears

In the obsessive mist of past ballads

We, the strange fruits of present chaos

Whose dreams are occupied

In tales of historica etiopics ${ }^{45}$.

Deceived by 'the songs our elders taught us', holding on to the 'deaf pride of antiquity', their dreams 'occupied in the tales of historica etiopics', their thoughts rooted 'in the obsessive mist of past ballads': Also of Etiopics vividly depicts and harshly condemns the intellectuals' empty fervour for the Great Tradition. What the old generation has transmitted to Șägaye's own generation are nothing but 'false songs', 'tales', 'ballads' of a romanticised past. In these tales, Șägaye's contemporaries took refuge, frightened by the 'winds of change' and refusing to assess the present for what it was. Absorbed in the glories of the past, hardened in their stubborn pride, Ethiopian thinkers removed themselves from the social reality around them. The whole poem is an angry accusation of failure against Ethiopia's educated elites, and Șägaye makes it clear that the unrealistic attachment to the Great Tradition is the main reason for the intellectuals' failure.

This alternative conception of history, for the most part, never translated to open political dissent. The intellectual class did not take part in the organization of the 1960 coup, for example, nor did they come out to support the coup once the Imperial Bodyguards took over the royal palace. Gärmame Nəway had indeed turned to his brother, the military commander of the Imperial Bodyguards, precisely because he had initially failed to enlist any like-minded intellectuals. For the middle generations, one can speak more accurately of a situation of ideological paralysis. Unsatisfied with the country's state of affairs but probably too comfortable in their secure jobs to proactively

\footnotetext{
${ }^{45}$ Șägaye Gäbrä-Mädhən [Tsegaye Gabre Medhen], 'Poems of Tsegaye Gabre Medhen', Ethiopia Observer (9:1), 56-7.
} 
This is the accepted version of a forthcoming article that will be published by Cambridge University Press in The Journal of African History: https://www.cambridge.org/core/journals/journal-of-african-history/all-issues

Accepted version downloaded from SOAS Research Online: http://eprints.soas.ac.uk/24350/

commit to systemic change, the middle generations proved 'unable or unwilling, ${ }^{46}$ to theoretically elaborate on their frustration.

Although the histories of failure did not seem to have had a concrete impact on the country's political situation, the anxiety felt by the old guard was motivated by the same structural problems that angered the students. The difference between these two generations in the 1960s had more to do, perhaps, with socio-economic incentives. While the older thinkers had secure and well paid jobs in the government, civil service or state-sponsored cultural institutions, the students graduated when unemployment was on the rise. Ideologically speaking, though, there is a clear continuity between the two cohorts: both are part of a decades-old ideological trend that foregrounded ideas of failure and decline against the Great Tradition's rhetoric of chosenness and exceptionalism.

\section{POST-1974}

From the 1970s onwards, the two-way connection between historiography and political practice became much more explicit. Under the guise of Marxist discourse, the Därg regime effectively preserved the imperial conception of Greater Ethiopia as a national identity transcending regional and ethnic 'particularism, ${ }^{, 47}$. The opposition to the Great Tradition, intuitively sketched out by the middle generations in their books and then openly championed by the students in the street, was now pursued by armed liberation movements on the battlefield. The connections between student organizations and rebel groups, in terms of leaders and ideas, were sometimes conspicuous, to the point that Gebru Tareke considers the civil wars of 1974-1991 as a second manifestation, rural and ethno-nationalist, of the Ethiopian revolution, as opposed to the urban parties that merged into the Derg or were eliminated during the Red Terror in the late $1970 \mathrm{~s}^{48}$. The 'national oppression thesis' proposed by Walällən̆ Mäkonnən, came to shape the historiographical position of the Tigrayan People's Liberation Front (TPLF). Ethiopian emperors, it was argued, are tyrants and criminals, and

\footnotetext{
${ }^{46}$ Taferra Work Beshah, 'The social background and the development of the new Ethiopian elite', (unpublished BA thesis, Haile Selassie I University, 1964).

${ }^{47}$ Toggia, 'History writing', 323.

${ }^{48}$ Gebru Tareke, Ethiopian Revolution: War in the Horn of Africa, (New Haven, 2013).
} 
This is the accepted version of a forthcoming article that will be published by Cambridge University Press in The Journal of African History: https://www.cambridge.org/core/journals/journal-of-african-history/all-issues

Accepted version downloaded from SOAS Research Online: http://eprints.soas.ac.uk/24350/

their authoritarian assimilationist policies oppressed Ethiopia's nationalities and negated their right to freedom of cultural expression. A second historical interpretation, the 'colonial thesis', was advocated instead by the Eritrean People's Liberation Front (EPLF), the Oromo Liberation Front (OLF) and the Western Somali Liberation Front (WSLF). Mənilək II’s nineteenth-century territorial expansion became a central polemical target. Celebrated in the Great Tradition as the reunification of the old 'Ethiopian nation', the conquests were now seen as an act of internal colonialism. The violence with which they were carried out, and the ideology of habäša superiority that inspired them, were the same as the violence and supremacist ideology of European colonialism. Haylä Səlasse's 1962 annexation of Eritrea, another long-awaited 'reunification' for the Great Tradition, was now similarly interpreted as colonial expansionism.

Two aspects of the Great Tradition were fiercely contested in those years, often in direct continuation with some of the positions taken by sub-factions of the ESN after 1969. The first, as we have seen, was the conception of the nation as transcendental and timeless. The second was the Great Tradition's parable of antiquity. This was reviled, for example, in the 1977 political programme of the EPLF:

There is a legendary history of '3,000 years' which Ethiopian feudalists and rulers have fabricated to expand their interests. The principal objective of the Amhara feudalists in concocting this tale is the realization of their expansionist ambitions: to put a large country under this dictatorship through the claim of ' 3,000 years' ${ }^{49}$.

The OLF similarly accused the Great Tradition of being an instrument of the Ethiopian ruling elite's expansionist ambitions in the Horn:

At no time before the conquest by Menelik was the present day Ethiopia a single country. What existed were independent polities. [...] The official Ethiopian history that [...] presents Menelik's era as 'the unification of Ethiopia' is a fabrication, pure and simple. As in the rest

\footnotetext{
${ }^{49}$ Quoted in Okbazghi Yohannes, 'The Eritrean question: a colonial case?', Journal of Modern African Studies, 25 (1987), 644-645
} 
This is the accepted version of a forthcoming article that will be published by Cambridge University Press in The Journal of African History: https://www.cambridge.org/core/journals/journal-of-african-history/all-issues

Accepted version downloaded from SOAS Research Online: http://eprints.soas.ac.uk/24350/

of colonial Africa, the Oromo and other southern peoples were subjugated, their peace, their cultural identities and human dignity deprived ${ }^{50}$.

How successful were these counter-historiographies in challenging the Great Tradition? Historians who promoted the national oppression thesis and the colonial thesis tended to legitimise their political claims using the same tools employed by the Great Tradition: antiquity, unity, authenticity. Reacting against 'oppressive conditions and denials of identity' Oromo studies understandably emerged, after decades of marginalisation, as an 'intrinsically ideological and emotionally-bound' scholarly field ${ }^{51}$. Oromo historians, for example, aimed at creating a 'usable past' and a 'usable identity' for the Oromo political resistance and nationalist project. In this sense, Oromo historiography was 'a modern statement of past glory and, inevitably, a by-product of cultural nationalism, ${ }^{, 52}$. A central goal of the new Oromo scholarship was giving a sense of identity to communities that had suffered discrimination. Triulzi argued that, to this end, Oromo historiography employed 'an upside-down version of the old paradigm of exclusion' and constructed 'new images of racialized differences and essentialized traits in the region, ${ }^{53}$. The new identity was constructed, in Triulzi's view, by strenuously defending a 'moral ethnicity which tended to isolate each community within its own cultural and linguistic bounds ${ }^{54}$. Other scholars argued that, particularly in its beginnings, Oromo historiography took 'the Ethiopianist position as its point of departure and, as a consequence, [remained] derivative, however hostile ${ }^{55}$. Based on similar considerations, Clapham finds it significant 'that the Ethiopian great tradition has become so entrenched in the construction of legitimating state ideologies in the region that the devotees of a new state [i.e. Oromia] should feel impelled to create a counter-tradition to accompany it ${ }^{56}$.

\footnotetext{
${ }^{50}$ OLF Foreign Relations Committee, The Oromo people in search of just peace, (Washington DC, 1999), 8-9.

${ }^{51}$ Triulzi, 'Battling', 279.

${ }^{52}$ Ibid.

${ }^{53}$ Triulzi, 'Battling', 286. This received criticism also from within the Oromo nationalist movement, see Kuwee Kumsa, 'Oromo women and the Oromo national movement: Dilemmas, problems and prospects for true liberation', in Asafa Jalata (ed.), Oromo nationalism and the Ethiopian discourse, (Asmara, 1998), 153-82.

${ }^{54}$ Triulzi, 'Battling', 280.

${ }_{55}^{55}$ Crummey, 'Ethiopian historiography', 16.

${ }^{56}$ Clapham, 'Rewriting', 59.
} 
This is the accepted version of a forthcoming article that will be published by Cambridge University Press in The Journal of African History: https://www.cambridge.org/core/journals/journal-of-african-history/all-issues

Accepted version downloaded from SOAS Research Online: http://eprints.soas.ac.uk/24350/

\section{FROM 1991 TO THE PRESENT}

A TPLF-led coalition of armed resistance movements, called EPRDF (Ethiopian People's Revolutionary Democratic Front), seized power in 1991, unseating the Därg. The new 1995 Constitution organised the state based on ethnic federalism and number of rights, including selfdetermination up to secession, to the 'nations, nationalities and peoples of Ethiopia', each assumed to be defined by a shared language, culture and territory. This process was all-too-easily described as the victory of the counter-narratives over the centralism and assimilationism of the Great Tradition.

From the point of view of state discourses, in the years after 1991 the EPRDF discouraged the use of imperial symbols of nationhood in public life. Former emperors, in line with the national oppression thesis, were disparaged for their human rights abuses and crimes against the Ethiopian people. The new government consciously turned to history to forge a new identity for the Ethiopian nation. This process required constant accommodation between the 'colonial thesis' largely expounded by Oromo political organizations, and the continuation of the Great Tradition, which came to be associated mostly, but not exclusively, with Amhara groups. The TPLF proposed instead a new regionalist version of highland nationalism based on Tigrayan historical achievements. The Aksumite empire, rather than the Solomonic saga, was presented as the first historical manifestation of Ethiopianness. In so doing, Ethiopian history 'lost' a thousand years, as the parable of Solomon and Sheba was traditionally dated back to a millennium before the rise of Aksum. While regionalist, the TPLF vision was also Pan-Ethiopianist, as the heritage of Tigray was thought to stand for the whole of the country.

The rulers' attitude towards historiography, though, remained pragmatic and goal-oriented, so that when a number of political developments made it convenient to resurrect the Great Tradition's symbolism, EPRDF party leaders did not hesitate to skilfully do so. In 1996, during the celebrations for the one hundredth anniversary of the battle of Adwa, the government sought to emphasise how the Tigrayans were the main agents behind the victory. But then, during the 1998-2000 war with Eritrea, 
This is the accepted version of a forthcoming article that will be published by Cambridge University Press in The Journal of African History: https://www.cambridge.org/core/journals/journal-of-african-history/all-issues

Accepted version downloaded from SOAS Research Online: http://eprints.soas.ac.uk/24350/

the memory of the battle was then refashioned as a symbol of Pan-Ethiopian resistance against foreign invaders - be they Italians, it was suggested, or their Eritrean successors.

Imperial iconography and ancient monarchical myths were further revived, as argued by $\mathrm{Bach}^{57}$, whenever the government needed to promote national unity, as when the OLF abandoned the ruling coalition and reverted to armed struggle against the new government. The Somali civil war and the Rwandan genocide, highlighting as they did the risks of ethnic particularism and sub-national group bonds, were similarly instrumentalised by the government in pushing for policies of PanEthiopian cohesion. The 2005 general elections, finally, revealed how, despite the government's efforts to leave it behind, the Great Tradition was all too alive. Some of the opposition parties whose rapid rise in popularity threatened the EPRDF had positions very close to the old imperial PanEthiopianism $^{58}$. The EPRDF managed to maintain its political supremacy, but in the aftermath of the elections, it started referring more conspicuously to the Great Tradition in its public rhetoric in order to prevent future challenges.

This concern was particularly evident in the way the EPRDF used the celebrations for the Ethiopian millennium in 2007-2008 to construct a new series of national myths that could transcend both ethno-nationalist claims and old imperial paraphernalia ${ }^{59}$. The new symbol for the nation (a secular reincarnation of the Queen of Sheba) was Lucy, the remains of a hominid discovered in the 1970s in the Afar Depression. Considered by scientists one of the earlier archaeological finds of early hominids, Lucy was hailed during the festival as the 'first Ethiopian'. In a reinvention of the Great Tradition's ideas of continuity and antiquity, Ethiopia was celebrated as the 'birthplace of humanity'. After shortening Ethiopian history by a thousand years, the EPRDF lengthened it again by several million years.

\footnotetext{
57 J.N. Bach, 'Compromising with Ethiopianness after 1991: The Ethiopian festival of the Millennium (September 2007-September 2008), Northeast African Studies, 13:2 (2013), 93-122.

${ }_{58}^{5}$ For example, the Coalition for Unity and Democracy (CUD, or Kənjət).

${ }^{59}$ Bach, 'Compromising', and I. Orlowska, 'Forging a nation: The Ethiopian millennium celebration and the multiethnic state', Nations and Nationalism, 19:2 (2013), 296-316.
} 
This is the accepted version of a forthcoming article that will be published by Cambridge University Press in The Journal of African History: https://www.cambridge.org/core/journals/journal-of-african-history/all-issues

Accepted version downloaded from SOAS Research Online: http://eprints.soas.ac.uk/24350/

The EPRDF's developmentalist nationalism prides itself on Ethiopia's double-digit economic growth, infrastructural projects and rapid urban development. In state-sponsored discourse, shiny skyscrapers, multi-level highways and the colossal Millennium Dam became the new rock-hewn churches and the new Fäsilädäs castles. Images of the Millennium Dam now appear on government diplomatic and touristic publications side by side with the long-established symbols of Ethiopianist nationalism, such as the Aksum's steles or Lalibäla's churches.

The state-sponsored nationalism in Ethiopia of today thus draws both from the Great Tradition and from the counter-historiographies. It attempts to accommodate both, and selectively emphasises one or the other. The contradictions between the two remain, and the new national ideology promoted by the EPRDF does not in any way represent a synthesis between the "nations, nationalities and peoples' on one side and the imperial heritage on the other.

If the Great Tradition and the counter-historiographies are somewhat made to coexist at the level of government ideological strategies, what is happening in academic historiography? How did history writing change after 1991? Scholars, mostly Western, who have commented on recent developments in Ethiopian historiography, have tended to lament that many studies by Ethiopian historians are overly determined by ideology and politics. They pointed at the one-sidedness of both the Great Tradition and the counter-historiographies, urging a methodologically rigorous integration of the two perspectives. Semir Yusuf doubts this will happen. In a 2009 article, he shows how Ethiopianist historiography on the one hand, and ethno-historiographies on the other, have become further entrenched, particularly as a result of diaspora politics. He contextualises this polarisation within the processes of deterritorialisation and reterritorialisation of nationalism typical of contemporary globalisation, concluding that 'the struggle for history and identity in Ethiopia will tarry in a glocal/transnational space ${ }^{60}$.

Some Ethiopian scholars openly defended politicised scholarship, underlining the ways in which history writing can and should serve emancipatory purposes. Asafa Jalata, for example, makes

${ }^{60}$ Semir Yusuf 'Contending', 315. 
This is the accepted version of a forthcoming article that will be published by Cambridge University Press in The Journal of African History: https://www.cambridge.org/core/journals/journal-of-african-history/all-issues

Accepted version downloaded from SOAS Research Online: http://eprints.soas.ac.uk/24350/

the point that intellectuals 'need to debate openly and honestly to transform their scholarship, and to suggest ways through which conflicts can be democratically and fairly resolved in the Ethiopian empire. The building of a democracy of knowledge is the first step toward this goal ${ }^{61}$. Merera Gudina argues that putting history at the service of political mobilisation, social movements or nationbuilding project has always been a universal trend, despite the scientific objectivity that the West claims for its scholarship ${ }^{62}$. Virtanen, although critical of the depreciation of diversity and intersectionality within mainstream Oromo nationalism, agrees that processes of essentialisation are 'are typically used by marginalized or subordinate groups for sustaining the identity of the community—and in informing resistance ${ }^{, 63}$. He proposes Bhabha's definition of 'strategic intellectuals' for contemporary Ethiopian historians ${ }^{64}$. Bhabha advocates a shift in the intellectual profession 'from the positivistic sense of rationality, as the possession of an a priori subject' to 'an attention to the place and time of the enunciative agency', with an increased 'emphasis on the relation between temporality and meaning in the present of utterance, in the performativity of a history of the present $^{, 65}$. Against the idea that the intellectual should produce knowledge that is universally valid in space and time, Bhabha encourages fellow scholars to engage in the political struggle around the definition of (social or historical) 'truth' through 'the strategy of speaking in a particular time and from a specific space', thus rejecting the notion that a 'pedagogical authenticity' could be 'secured as an epistemological "outside",66.

\footnotetext{
${ }^{61}$ Asafa, Oromo nationalism, 275.

${ }^{62}$ Merera Gudina, 'Ethiopia: Competing Nationalisms and the Quest for Democracy, 1960-2000', (unpublished $\mathrm{PhD}$ thesis, The Hague Institute of Social Studies, 2002), 101.

${ }^{63} \mathrm{P}$. Virtanen, 'Rewriting Oromo history in the north: Diasporic discourse and national identity and democracy in Ethiopia', Diaspora 18:3 (2009), 274.

${ }^{64}$ Though he limits his discussion to Oromo scholars, his reasoning can easily be applied to Ethiopianist scholars as well.

${ }^{65}$ H. Bhabha, 'Postcolonial authority and Postmodern guilt', in G. Nelson and P. Treicher (eds.), Cultural Studies, (New York, 1992), 57.

${ }^{66}$ Ibid.
} 
This is the accepted version of a forthcoming article that will be published by Cambridge University Press in The Journal of African History: https://www.cambridge.org/core/journals/journal-of-african-history/all-issues

Accepted version downloaded from SOAS Research Online: http://eprints.soas.ac.uk/24350/

\section{CONCLUSIONS}

In the twentieth century, Ethiopian conceptions of history became increasingly rigidified in one hegemonic critical paradigm, generally referred to as 'Great Tradition'. The Great Tradition is characterised, first, by a teleological vision of history based on the prophecy of Ethiopia's earthly glory and eschatological victory, and, second, by an essentialist, transcendental and unicentric conception of national, sub-national and individual identities. Central to the Great Tradition is the cult of the monarchy as divinely-ordained, and the first cohorts of twentieth-century intellectuals never strayed from a hierarchical idea of society with the emperor at the top. Alongside the Great Tradition, other political interpretations of Ethiopia's present and past took shape in the years following the 1896 Adwa victory. These challenges varied, but all revolved around the notion of failure: the failure of development and democratisation. Contrary to the Great Tradition's prediction of an ever-increasing Ethiopian greatness, these alternative conceptions of history focused on Ethiopia's lack of economic progress, shaky national cohesion, and international weakness.

In contemporary Ethiopian studies, it is generally assumed that it was the Ethiopian Student Movement that coined these counter-hegemonic visions of history. Although the student generation marked a significant change in Ethiopian intellectual history, overstressing the idea of a radical break with the past overshadows the elements of similarity between the students and their seniors. Intergenerational ideological relations within the secular intellectual elite in the 1960s and 1970s are better understood by looking at long-term continuities rather than assuming abrupt ruptures.

The old generations, particularly those born in the 1930s and active in the 1960s, had already articulated ideas of national decline and historical failure. Many attacked their peers for their inability or unwillingness to commit to social change. Although profoundly disillusioned with the country's state of affairs, they proved reluctant to dismiss the Great Tradition altogether, and held onto it against the ever-growing empirical evidence that the destiny of glory it anticipated for Ethiopia had failed to materialise. The Great Tradition was perceived to have such a reassuring and time-tested explanatory 
This is the accepted version of a forthcoming article that will be published by Cambridge University Press in The Journal of African History: https://www.cambridge.org/core/journals/journal-of-african-history/all-issues

Accepted version downloaded from SOAS Research Online: http://eprints.soas.ac.uk/24350/

power that no alternative ideological options were believed to be as viable. At the same time, this ideological impotence caused, by the old intellectuals' own admission, an acute sense of apprehension and anxiety. In stark contrast with their elders, the students took to the streets, mobilised collectively, and increasingly embraced an ideology, Marxism, that up to that moment had not had any traction in Ethiopian political thought. Despite choosing profoundly different ideological and practical responses, the two generational cohorts agreed on the same diagnosis of national stagnation.

Among the secular elites, the Great Tradition has always been the most politically and symbolically powerful version of Ethiopian nationalism, but it was never all-powerful. For the intellectuals under analysis, the belief in progress was always intertwined with a fear of failure. The contrast between the Great Tradition's exceptionalist claims and the country's lacklustre reality were at the basis of a widespread historiographical anxiety, but were also, and at the same time, the source of the intellectuals' historical creativity and social engagement.

The Great Tradition and the contrasting visions of a 'failed' or 'failing' national history proceeded side by side during the course of the twentieth century. In such parallel journey, they shared some basic premises: an essentialist and transhistorical view of identity, constructed in binary opposition to a radically antithetical cultural 'other'. Both claimed legitimacy by appealing to antiquity, authenticity and unity. For Crummey, this means that the counter-historiographies remain 'derivative, however hostile ${ }^{97}$. At the level of state elites, the power relation between the two changed over time; the virtually uncontested hegemony of the Great Tradition was gradually eroded in the second half of the century. But more than deriving from one another, excluding one another, or overpowering one another, the Great Tradition and the counter-histories are ultimately to be conceived, as I have argued, in terms of a long-standing 'complimentarity' 68 .

\footnotetext{
${ }^{67}$ Crummey, 'Ethiopian historiography', 16.

${ }^{68}$ Bach, 'Compromising', 100.
} 